\title{
Research for Forming up the Controlling Diagram Utilizing the Connection of a LV Resistor on Voltage Transformer's Open-Triagle Coil to Reduce over Voltage Caused by Earth Fault in $6 \mathrm{kV}$ Grid of QuangNinh Underground Mines
}

\author{
Ho Viet Bun ${ }^{1, *}$, Le Xuan Thanh ${ }^{1}$ \\ ${ }^{1}$ Department of Electrification, Electromechanic Faculty, Hanoi University of Mining and Geology, \\ Viet Nam
}

\begin{abstract}
Single phase earth-fault in MV grids usually causes overvoltage that harm to human being and electric equipment. If the magnitude of over voltage is so great, many grids' eco-technical parameters will be affected. The paper analyzes all possible consequences of over voltage occurred in $6 \mathrm{kV}$ grid of QuangNinh underground mines. Base on the analysis, a controlling diagram utilizing the connection of a LV resistor on voltage transformer's open-triangle coil to reduce over voltage is recommended. The simulation results of the diagram are used to prove the effectiveness of solution: the over voltage magnitude is only in the range of $(2,1-2,4)$.Uf. Other advantage that solution brings to relay system will be pointed out. Key word - earth fault, over voltage, open-triangle coil, $6 \mathrm{kV}$ grid.
\end{abstract}

\section{Introduction}

Earth faults are very popular phenomenon in $6 \mathrm{kV}$ grids of QuangNinh underground mines. The ratio of this fault is about 55 to $73 \%$ [2] of the total faults in power system. It usually occurs with arc, especially in storm season. Some cases, earth fault happened with continuing arcing over voltage which is the most dangerous phenomenon (in the field of appearing and distinguishing the arc), [3-5]. The first damage of arcing over voltage is the insulation destroying.

This kind of over voltage depends on some main matters: quantity and property of the circuit, recovery voltage of grid right after the fault. Moreover, the transient of arcing over voltage depends also on contacting resistor, the contacting momentary and the location of earthing. According to researches presented in [3-5], the value of voltage on unfaulted phases is vary from 2,1 Uphase to 4, 6 Uphase.

\footnotetext{
Corresponding author: hovietbun@gmail.com
} 
Base on the above analysis, in $6 \mathrm{kV}$ grid of QuangNinh underground mines, it is necessary to form up the model for determining correctly the earthing moment in order to connect a LV resistor to reduce arcing over voltage.

\section{The application of Microprocessor on determining the earthing momentary in order to connect a LV resistor to reduce arcing over voltage}

\subsection{Diagram of connecting LV resistor to reduce arcing over voltage}

There are many solutions to reduce over voltage; however, because of strict safety regulation in underground mines, connecting a LV resistor is optimal and effective solution that does not change the property of neutral point [1]. To implement the connection, a special transformer is arranged on $6 \mathrm{kV}$ bus bar, the resistor is connected to its open-triangle coil. The connection diagram is shown in Figure 1. In this diagram the special transformer is connected to the bus bar through circuit breaker B4, LV resistor RH is controlled by microprocessor corresponding to the value of $3 \mathrm{U} 0$.

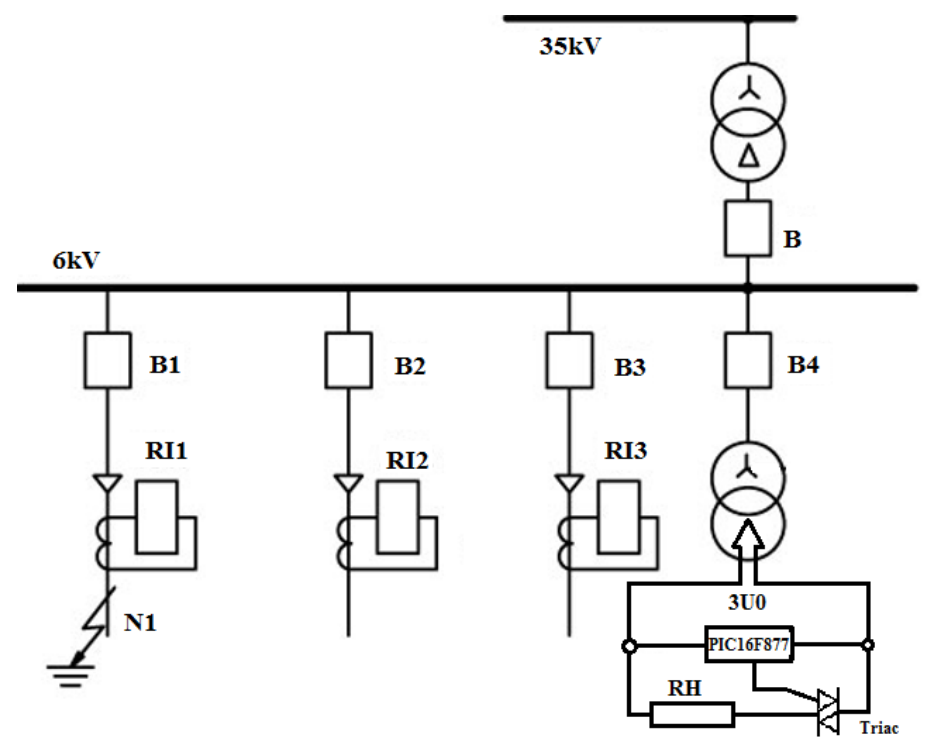

Fig. 1. The connection diagram of LV resistor on open-triangle coil of a $6 \mathrm{kV}$ special transformer

\subsection{Block diagram of controlling method utilizing microprocessor}

In Figure 1, microprocessor PIC16F877 is used to generate controlling signal for connecting or disconnecting RH on the LV side of transformer. The requirements for over voltage relay tripping time must be lower than $5 \mathrm{~ms}$ [2]. Block diagram expressing the fault determining process and controlling operation of Triac KS200A is shown in Figure 2 and 3. 


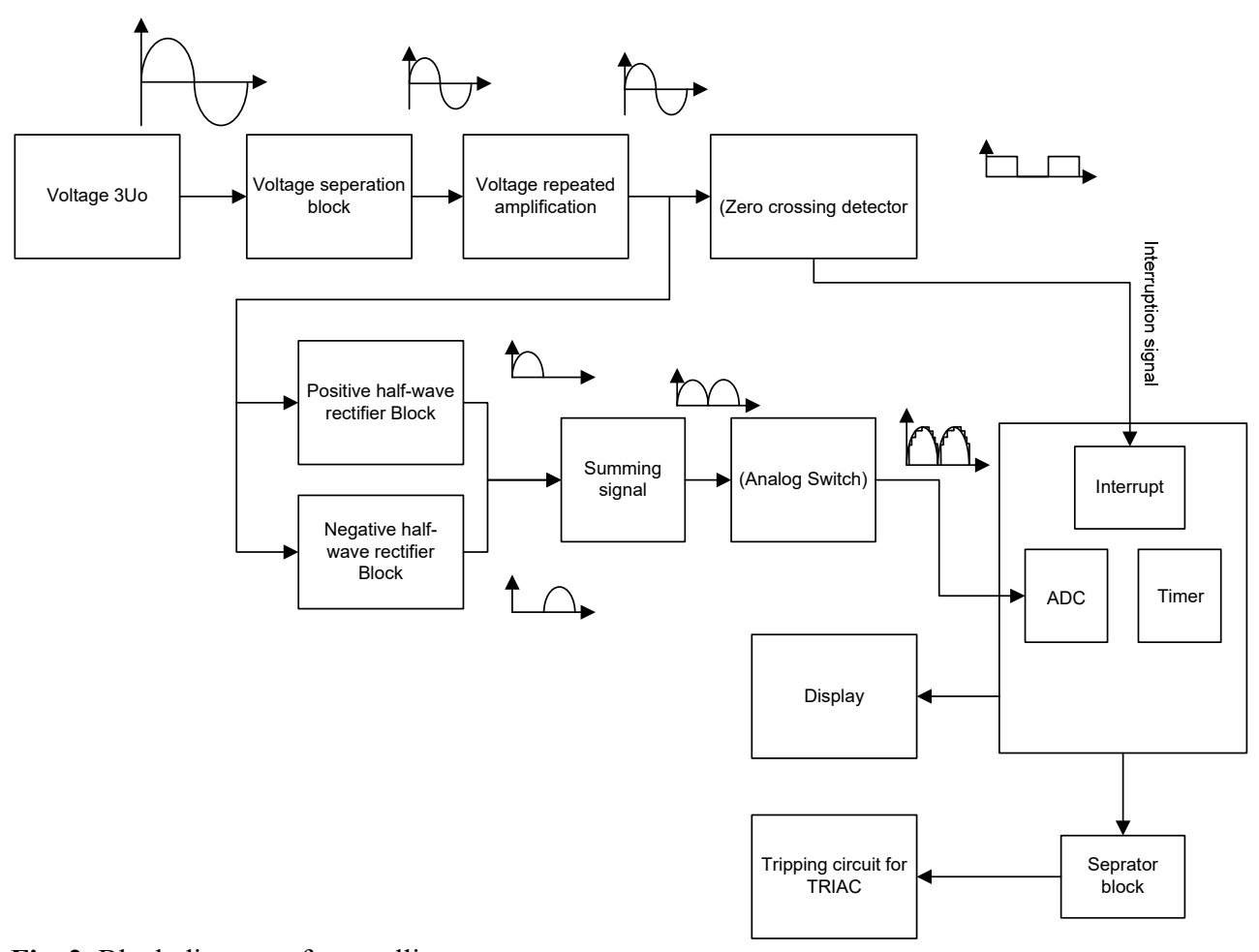

Fig. 2. Block diagram of controlling process

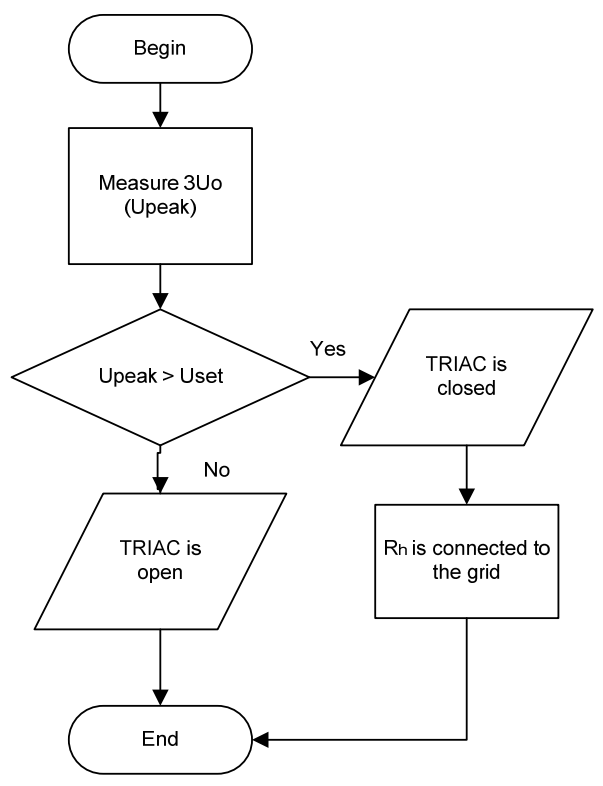

Fig. 3. Mathematic diagram of PIC 16F877 controlling process

\subsection{Calculation, simulation and results}

Using Proteus software to form up the controlling process, the diagram is shown in Figure 4. 


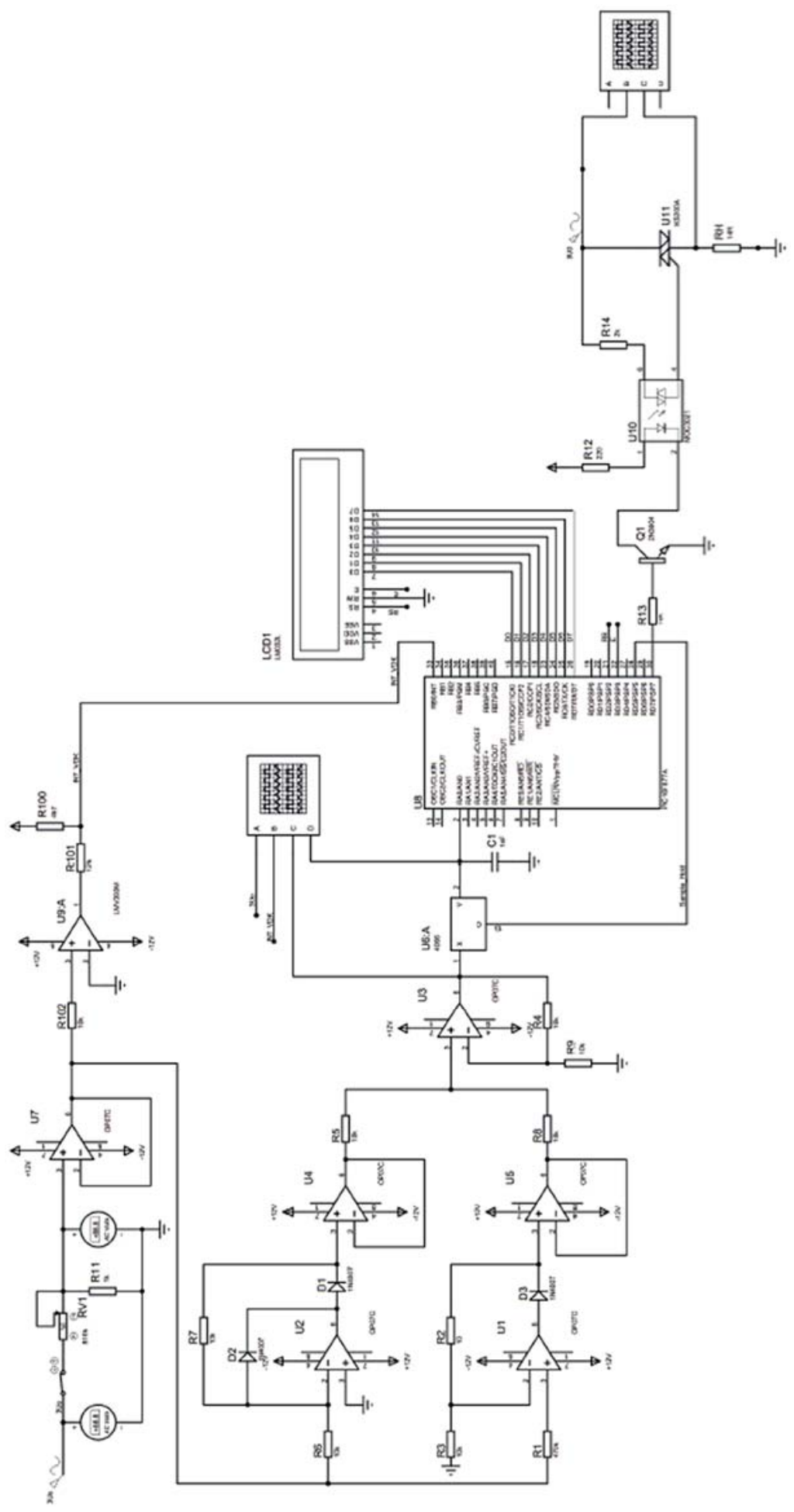

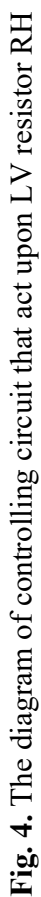


The simulation results are shown in Figure 5 to 9.

\begin{tabular}{|c|c|c|c|}
\hline \multicolumn{2}{|c|}{ Es Sine Generator Properties } & & \multirow{2}{*}{$\begin{array}{l}\text { ขปx } \\
\mathbb{a}\end{array}$} \\
\hline Geneator Name. & Oltses (Noks) & $\Gamma$ & \\
\hline 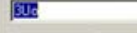 & \multicolumn{3}{|c|}{ Amaluide Notat: } \\
\hline Andogue Types: & - Ampliuder & $\sqrt{11}$ & 固 \\
\hline $\begin{array}{l}\text { DC } \\
\text {. } \sin \theta\end{array}$ & ¿Peok & & (1) \\
\hline$S_{\text {Pute }}^{\text {Puse }}$ & CAMS: & 1 & $\mathrm{~B}$ \\
\hline$\Delta$ File & \multicolumn{3}{|c|}{- Tming } \\
\hline $\begin{array}{l}\text { Audo } \\
\text { Exponerk }\end{array}$ & - Frequency $\mid \mathrm{Hz}$ & 5 & 国 \\
\hline$<$ SFFM & ¿Period (Sect) & & 回 \\
\hline CEasy HDL & SCycles/lisoph & & 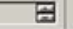 \\
\hline Diplal Iyper & \multicolumn{3}{|l|}{ Delay } \\
\hline \multirow{3}{*}{ 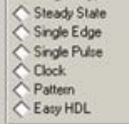 } & \multirow{2}{*}{$\begin{array}{l}\triangle \text { The Delay (Secs) } \\
\text { - Phare (Degrees) }\end{array}$} & & 目 \\
\hline & & To & 国 \\
\hline & \multirow[t]{2}{*}{ Dancing Foctor $[1 / 0)$} & \multirow[t]{3}{*}{ 0} & \multirow[t]{3}{*}{ 圆 } \\
\hline $\begin{array}{l}\text { Farent Sounce? } \\
\text { Fislote Betore? }\end{array}$ & & & \\
\hline $\begin{array}{l}\text { Manual Edits? } \\
\text { Wide Piopertiet? }\end{array}$ & OK & & \\
\hline
\end{tabular}

Fig. 5. Set the $3 \mathrm{U} 0$ threshold as $1000 \mathrm{~V}$

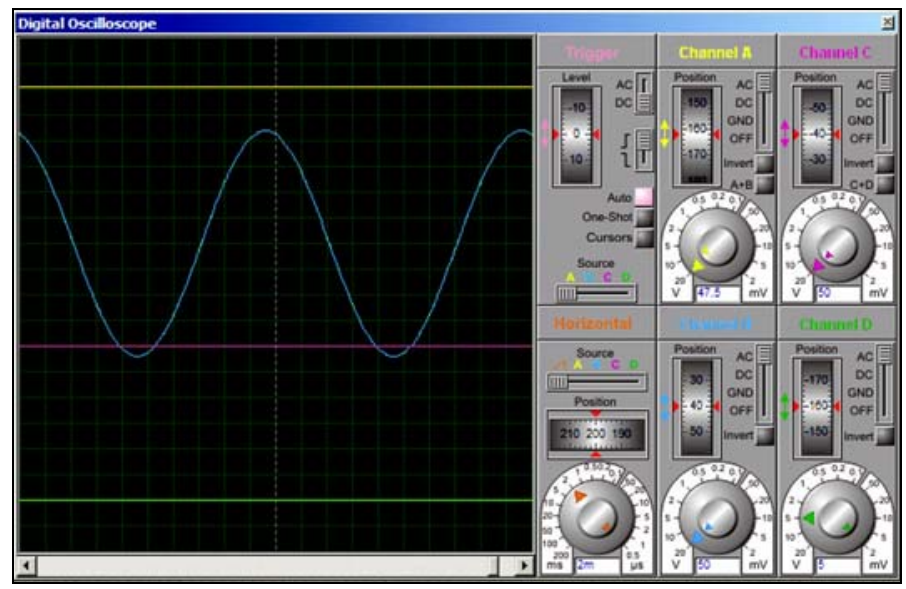

Fig. 6. $3 U 0=9 \mathrm{~V}$ (cyan) and voltage across LV resistor (violet)

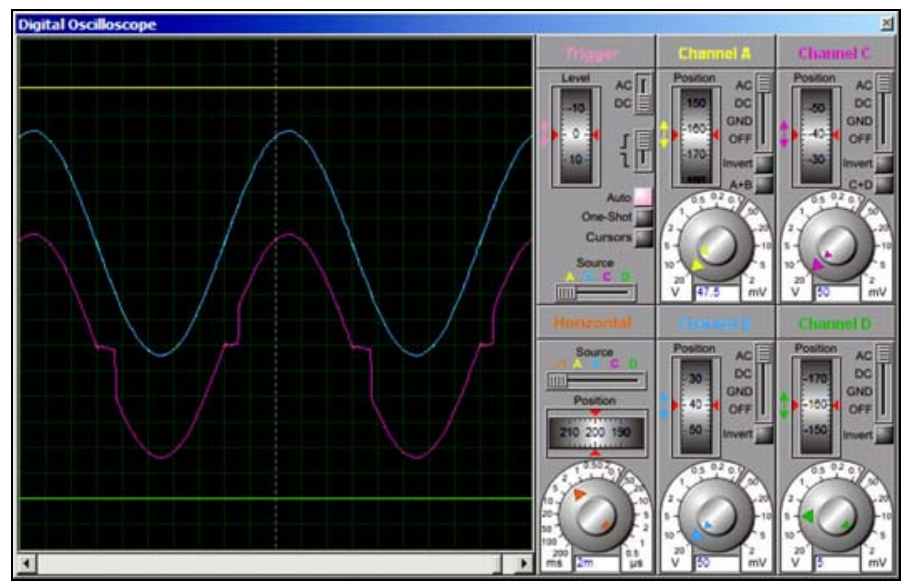

Fig. 7. Value of $3 \mathrm{U} 0=1 \mathrm{kV}$ (cyan) and voltage across $\mathrm{LV}$ resistor (violet) 


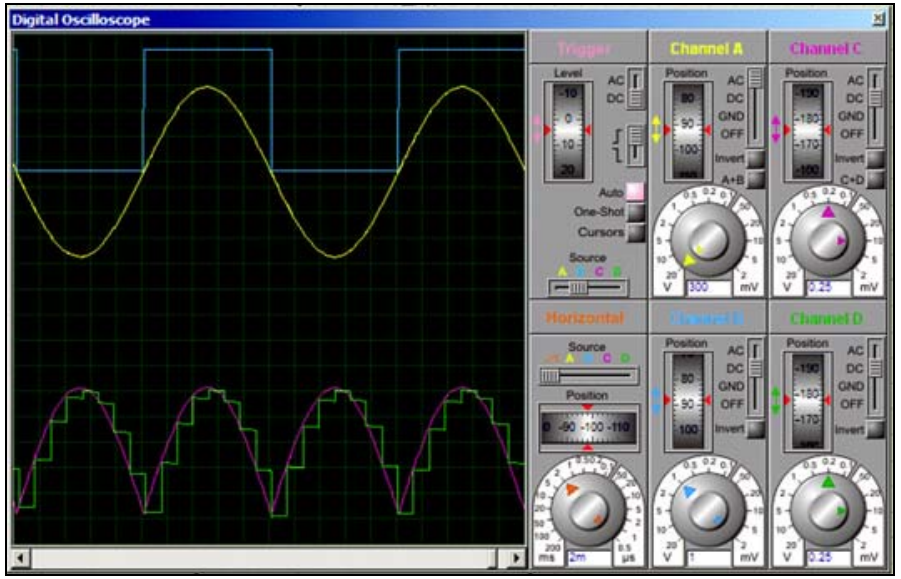

Fig. 8. Value of $3 \mathrm{U} 0=1 \mathrm{kV}$ (cyan) and voltage across LV resistor (violet)

Base on datasheet and the simulation results, the response time of OPAM is 1,3 $\mu$ s, opto MOC3021 time $(1 / 200 \mathrm{kHz})$ is $5 \mu \mathrm{s}$, switching time 4066 is $(1 / 40 \mathrm{MHz})$, sampling time and calculation procedure $500 \mu \mathrm{s}$ and Triac KS200A response is $1 / 100 \mathrm{kHz}=10 \mu \mathrm{s}$. Therefore total response time of circuit is $\leq 1 \mathrm{~ms}$.

The proof of using LV resistor in earthing process is shown in Figure 9.

a)
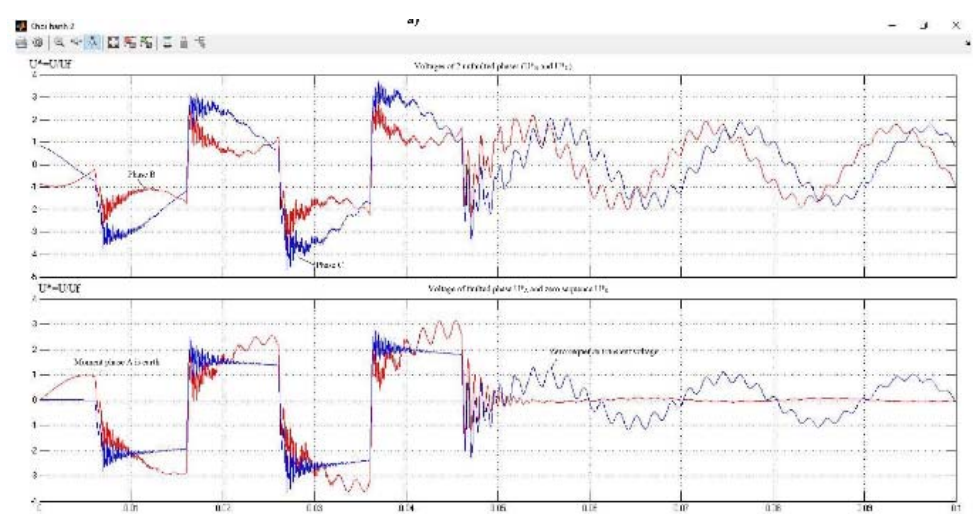

b)

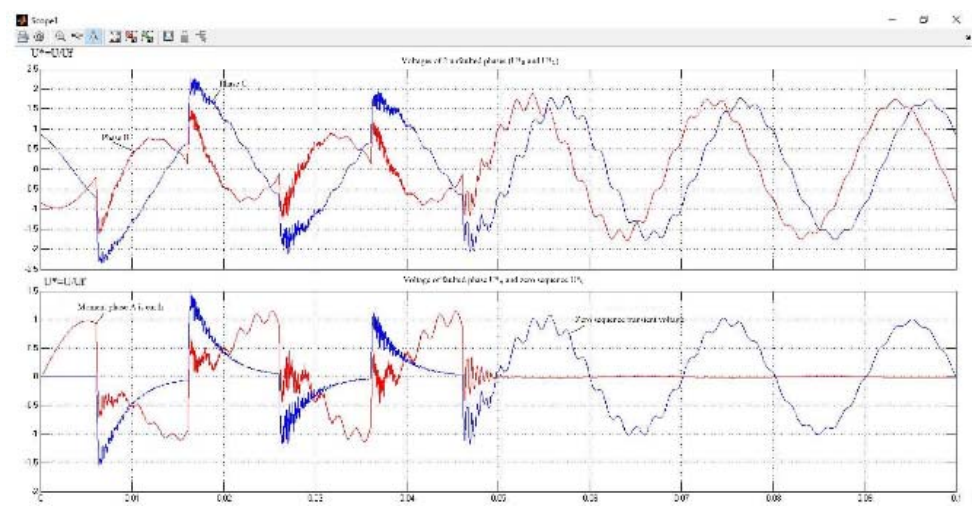

Fig. 9. Waveform of voltage transient when there is earth fault; a) without RH b) with RH is connected right the moment of earthling 


\section{Conclusion}

The paper presented a very suitable method to reduce the over voltage when there is an earth fault in mining grid. The suggestion methodology using a LV resistor to connected to $6 \mathrm{kV}$ bus bar through a special transformer does not violate the hazard regulation in underground mining, but it reduces significantly the magnitude the over voltage (as shown in Fig. 9). This over voltage value is only in the range of $(2,1-2,4)$.Uf. The range is falled within the accepted one rated in National regulation applied for electric equipment [1].

\section{References}

1. Ministry of Industry and Trade, National technical code of under ground mining, QCVN 01:2011/BCT, (2011)

2. Hồ Việt Bun, Reasearch and evaluate overvoltage transience caused by single phaseground failures in Cam Pha-Quang Ninh underground mines' $6 \mathrm{kV}$ grid, International conferrence of Advanced in Mining and Tunelling 21-22 October 2014, Vung Tau, Viet Nam, pp. 409-411, (2014)

3. Б.И. Базылев, А.М. Брянцев, А.Г. Долгополов и др, Дугогасящие реакторы с автоматической компенсаџией емкостного тока замыкания на землю, СПб.: Изд. пэипк, (1999)

4. Г.А. Евдокунин, С.С. Титенков, Внутренние перенапряжения в сетях 6-35кB, СПб: Издательство Терция, (2004)

5. Р.А. Вайнштейн, Н.В. Коломиец, В.В. Шестакова, Режимы заземления нейтрали в электрических системах, Томск: Изд-во ТПУ, (2006) 